中心と重心のズレの影響と共に以下述べる部材力変換の 際これを考慮している。

丸鋼材節点 $\mathrm{G}^{\prime}$ におりる部材力を $f_{i}{ }^{\prime}$ ，チャンネル材 重心 $\mathrm{G}$ からの距離をそれぞれ固定座標系に関して $y, z$ とすれば $f_{1}{ }^{\prime}, f_{2}{ }^{\prime}, f_{3}{ }^{\prime}$ により $\mathrm{G}$ 点で次のモーメントを 受ける。

$\begin{array}{ll}X \text { 軸に関して } & f_{2}{ }^{\prime} z-f_{3}{ }^{\prime} y \\ Y & -f_{1}{ }^{\prime} z \\ Z & f_{1}^{\prime} y\end{array}$

ところが $X$ 軸回りのモーメントに関してはチャンホ ル材の剪断中心で考学れば，重心軸から剪断中心軸まで の距離を $s$ として $f_{2}{ }^{\prime} s$ 方加算される。これと $f_{1}{ }^{\prime} \sim f_{6}{ }^{\prime}$ 自 身の直接伝達される力拉よびモーメントを加わ兄れば, マトリクス表現して

$$
\begin{aligned}
& f=T_{f} f^{\prime} \ldots \ldots \ldots \ldots \ldots \ldots \ldots \ldots \\
& f=\left\{f_{i}\right\} \\
& f^{\prime}=\left\{f_{i}^{\prime}\right\} \quad i=1,2,3, \cdots, 12
\end{aligned}
$$

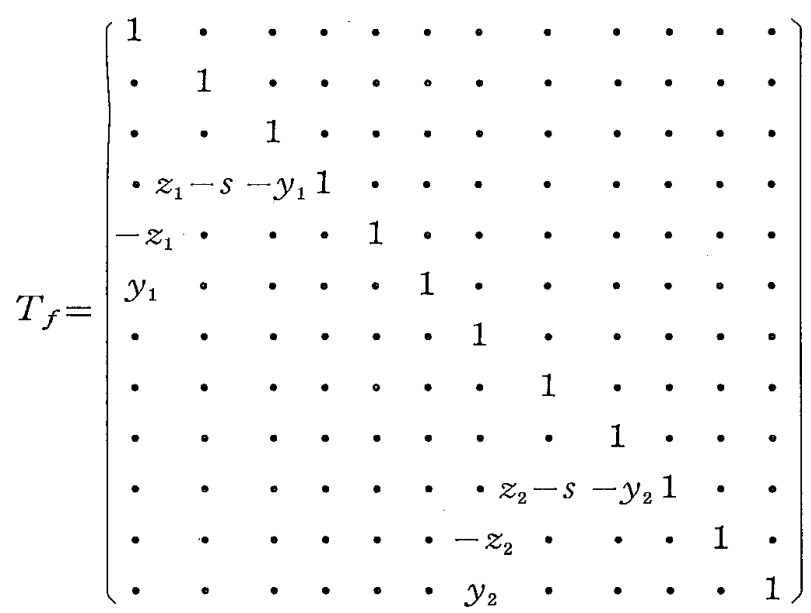

変位についても同様にして $\mathrm{G}$ 点での各軸回りの回転 $u_{4}, u_{5}, u_{6}$ に伴って $\mathrm{G}^{\prime}$ 点では次の変位が生ずる。

$$
\begin{array}{ll}
X \text { 軸方向に } & -z u_{5}+y u_{6} \\
Y & z u_{4} \\
Z & -y u_{4}
\end{array}
$$

$X$ 軸回りの $u_{4}$ はさらに反り変形と上記の移動から $Y$, $Z$ 軸回りに次の回転を生ぜしめる。

$$
\begin{array}{ll}
Y \text { 軸に関して } & y u_{4} / l \\
Z & z u_{4} / l
\end{array}
$$

反りは次式により求められる。

$$
\omega=\int_{e} r d e
$$

ここで $r$ 注断面中心線上 $e$ なる点での重心より垂し た垂線の長さを，また $\int_{e}$ はりり 0 となるところから $\mathrm{G}^{\prime}$ 点までの中心線に沿っての積分を表わしている。以上の 結果から変位に関する変換マトリクスは次のように導き 出される。

$$
\begin{aligned}
u^{\prime} & =T_{u} u \\
u^{\prime} & =\left\{u_{i}{ }^{\prime}\right\} \\
u & =\left\{u_{i}\right\} \quad i=1,2,3, \cdots, 12
\end{aligned}
$$

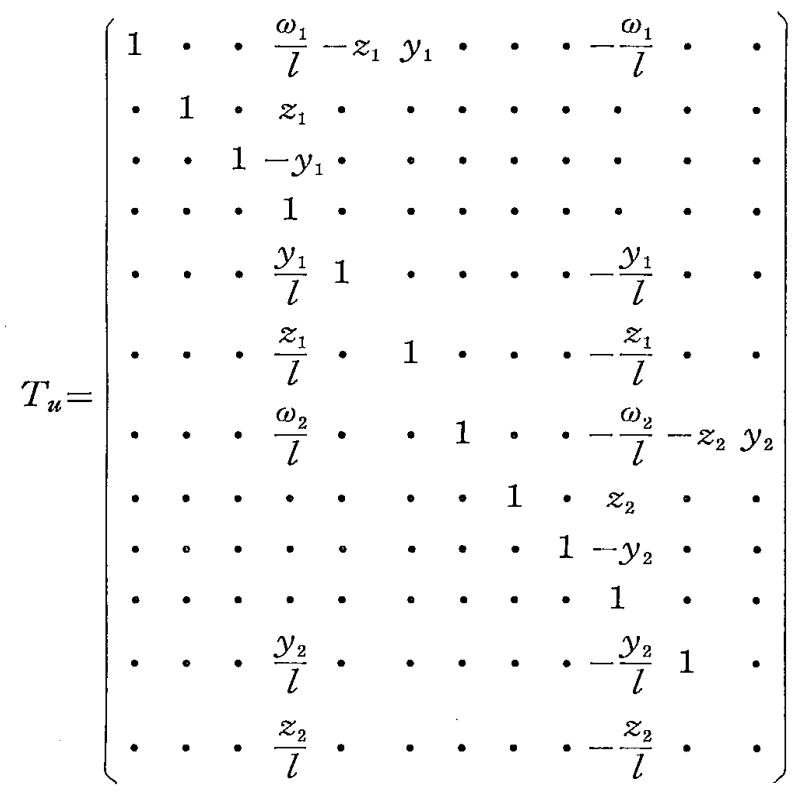

結局 (1) 式は (2) 式叔よび (3) 式によりさらに次のよ らに変換されることになる。

$$
K=T_{f} T^{T} k T T_{u}
$$

$K$ の任意要素 $K_{i j}$ の持つ意味は $j$ - 変位方向に単位 変形させた時に生ずる $i$ - 応力方向に生ずる力を表わす ことから各要素を次の変位番号および応力番号により架 構全体に対する剛性マトリクス $[K]$ の各要素ヘコンピ ューター内で自動的に組み込まれる。変位番号とは便宜 上の全末知変位に対する通し番号で，次の規則に従って 変位の幾何学的性状を容易に導入することが出来る。

1. 変位の絶対量の等しいものには同番号をもって表 わす。

2. 変位の方向性は+，一の符号による。

3. 不変のものについては 0 を用いる。

これに対して応力番号汇通常この変位番号と等しいが 同番号を二つ以上含む場合，この未知数に対する釣合式 がそのらちの一つで足りることから任意の一つを除いた 残りの全てを 0 に置き換えることが出来る。図--1 (c) の $i$ 部材について例にとればこの変位番号は $(0,0,0,0$, $1,2,3,4,5,-6,-7,-8)$ で，これが全剛性マトリク ス $[K]$ に刘する $i$ 部材剛性 マトリクスの列番号とな り，応力番号をこれと等しくとれば同時に行番号とな る。これから $i$ 部材剛性マトリクス要素 $K_{10.5}$ は全剛性 マトリクスの 6 行 1 列要素に $-K_{10.5}$ として加算され， $K_{i 4}$ や $K_{1 j}$ 等は読み捨てられる。

すなわち行・列番号が異符号の場合その部材剛性マ下 リクス要素は逆符号にして全岡性マトリクスに加算され いずれか一方に 0 を含めばこの要素は読み捨てられる。 これを全部材について行なえば結局全未知数に対する連 立方程式が得られ，全未知変位ベクトルを $\{U\}$ 全外力 ベクトルを $\{F\}$ で表わせば次式により解が得られる。

$$
\{U\}=[K]^{-1}\{F\}
$$

既知外力として強制変位を与える場合，全変位数を $n$ 強制変位数を $m$ とすれば $n-m$ 元に減ずることが出来 
る。強制変位を $\{\delta\}$ で区別すれば

$$
\left\{\begin{array}{l}
0 \\
P
\end{array}\right\}=\left[\begin{array}{ll}
K_{11} & K_{12} \\
K_{21} & K_{22}
\end{array}\right]\left\{\begin{array}{l}
U \\
\delta
\end{array}\right\}
$$

$\{P\}$ 溞制変位に必要な外力である。これから $\{U\}=\left[K_{11}\right]^{-1}\left(-\left[K_{12}\right]\{\delta\}\right)=\left[K_{11}\right]^{-1}\left\{F^{\prime}\right\}$

上式を（5）式と比較すれば $\left\{F^{\prime}\right\}$ は丁度外力ベクトル に相当することがわかる。

組立梁の㨭り剛性は反りを含まない平面トラス梁のよ うな場合と図-1-1 (b) に示すような Box Section Girder では，その性状においてかなりの差が見られる。特に鋼 管トラス梁では各部材自身の据り剛性は高いが組み立て られたことによる岡性の増加はさほど期待は出来ない。 両者にその弦材へ 1 﨎の隅力を与穴て梁の据り角 $\theta$ と弦 材自身の据り角 $\beta$ を比較して好ると，平面トラス梁では

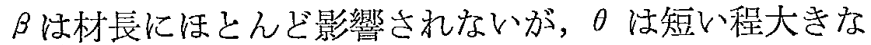
值を示す。これは材長が短いと両弦材が完全に据られず 単に水平変形を起すためで，長くなる程 $\beta$ に近づく。 $\theta$ は梁の㨝り剛性と反比例関倸にあり無限長梁については 1 ユニットをその端部断面形不変として強制㨝り変形さ せた場合にほぼ一致する。これに対して後者の場合，丸 鋼の雨弦材反り拘束のため $\beta$ 法波状に変化する。このた め梁が長くなる程据り剛性が增加するという平面卜ラス 梁と同様の傾向は示すが，断面形を不変として据った場 合の值より大きくなる。

この種の組立梁の据り耐力は雨弦材に比して腹材の丸 鋼の岡性が压倒的に低いことから狄鋼部材についてのみ 考慮すれば十分である。特に反り拘束による軸力が著し るしく，耐力ほほとんどこれによるものとみてよい。図 -2 は次節の据り実験によって得られた㨝り剛性の低下 曲線との比較図で，軸力について完全塑性体として求め たものが曲線Aである。実験ではそのほとんどが圧縮丸

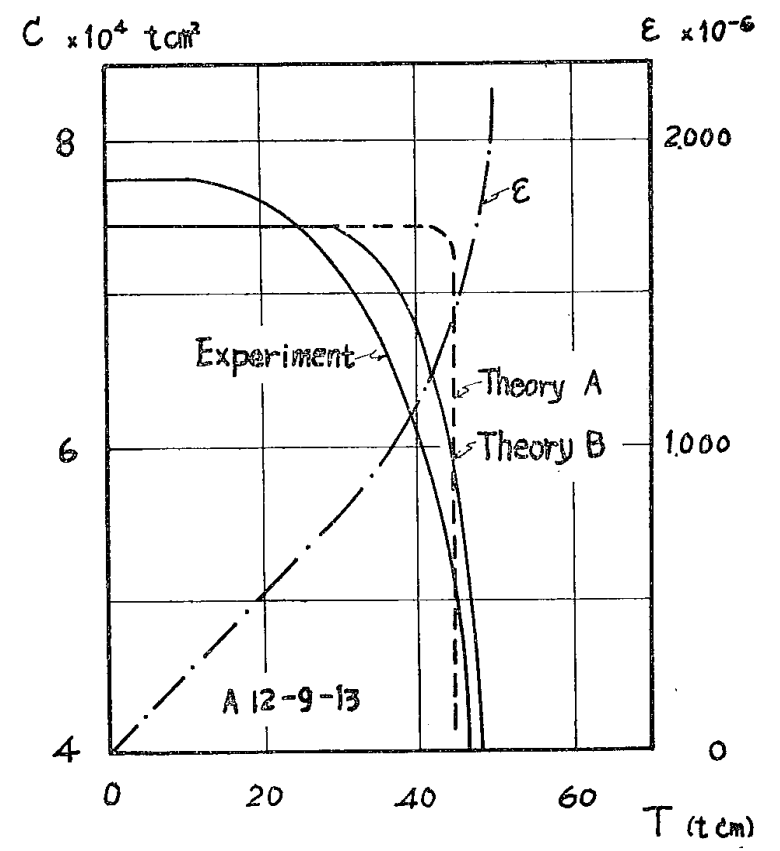

図-2 㨭り剛性低下曲線
鋼の座屈崩壇によっておうり，曲げと压縮を含むかなり複 雑な問題となる。しかし捩り崩壊トルクはほぼ丸鋼軸力 の降伏值に合っている。また岡性の低下過程の差は圧縮 丸鋼の付加曲げモーメントの影響が考元られるが，材料 引張試験より求められた応力-歪曲線から Tanget Modulus 理論により補正すればかなり実験曲線に近づく。

\section{§.据り实験}

\section{実験概要}

実験装置はコンクリートブロック 4 基上の長さ $2.8 \mathrm{~m}$ Hビーム $(200 \times 200) 2$ 本の上にセットされたもので, 可動支点部と不動支点部抒よびトルクを与它る载荷部か らなっている。トルクは可動支点部より突出した $1.6 \mathrm{~m}$ のI ビーム端に下げられた载荷台に順次錘りをのせるこ とにより生ぜしめるものである。両支点部は $13 \mathrm{~mm}$ 厚 プレートで熔接により組み立てられた幅 $40 \mathrm{~cm}$ 高さ, 奥 行がそれぞれ $24 \mathrm{~cm}, 15 \mathrm{~cm}$ の Box で試験体材端を 2 本 の $19 \mathrm{~mm} \phi$ 丸鋼とク步ビにより固定させ，反り変形を自 由にして㨝られるよう工夫されている。この可動支点部 は $60 \mathrm{~mm} \phi$ 丸鋼により載荷反力を伝え，他端の㨭り反力

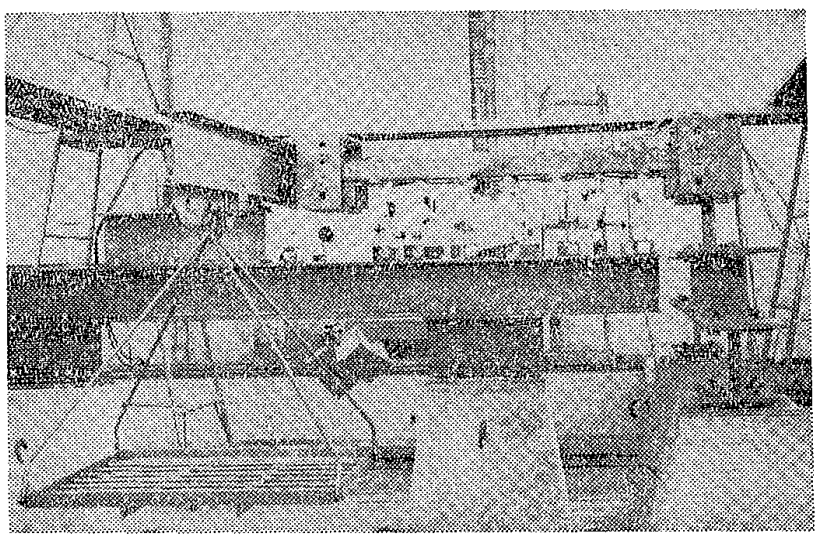

写真一1 㨭り实験装置

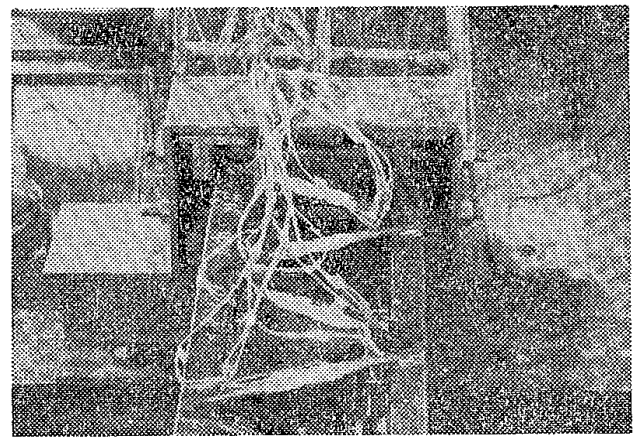

写真一2 不動支点部

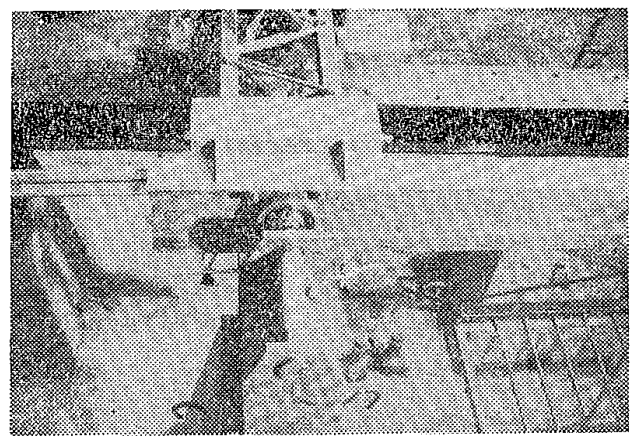

写真-3 可動支点部 
はHビーム両端のコンクリートブロックによりとってい る。60 mm $\phi$ 姯鋼と可動支点部とは自由に回転出来てし かも水平を保たせるために 2 個のベアリングにより支え られ，さらに試験体材長の変化に伴いこの部分はHビー ム上のスライドを可能にしている。

試験体は，両弦材にリップミゾ型鋼を用いた丸鋼によ る刘称断面のダブルワーレントラス A type と, リップ ミゾ型鋼開口部に丸鋼で補剛した非効称断面 B type の 2 種類で，それぞれ材端板厚，材長，丸鋼径を変化させ た計 11 体である。各形状，寸法は表一1 および図一3に 示す。試験体材料の機械的性質は表一 2 の通りで 2 type に使用されている全鋼材に対して引張試験を行なったも

表一1 試 験 体

\begin{tabular}{|c|c|c|c|c|}
\hline & 时 & $l$ & 端 部 板 & 丸 \\
\hline \multirow{7}{*}{ A } & A $6-9-13$ & 600 & 要 9 & $13 \phi$ \\
\hline & A $12-0-13$ & 1,200 & $ナ V$ & $13 \phi$ \\
\hline & A $12-9-9$ & 1,200 & $\Phi$ & $9 \phi$ \\
\hline & A $12-9-13$ & 1,200 & E 9 & $13 \phi$ \\
\hline & A $12-9-16$ & 1,200 & IE 9 & $16 \phi$ \\
\hline & A $12-19-13$ & 1,200 & 患 19 & $13 \phi$ \\
\hline & A $18-9-13$ & 1,800 & 都 9 & $13 \phi$ \\
\hline \multirow{4}{*}{ B } & $B-6$ & 1,200 & $ナ \quad V$ & $6 \phi$ \\
\hline & B- 9 & 1,200 & $ナ \quad$ ン & $9 \phi$ \\
\hline & B-13 & 1,200 & $ナ \quad V$ & $13 \phi$ \\
\hline & B-16 & 1,200 & ナ & $16 \phi$ \\
\hline
\end{tabular}

表一2 材 料 試 験

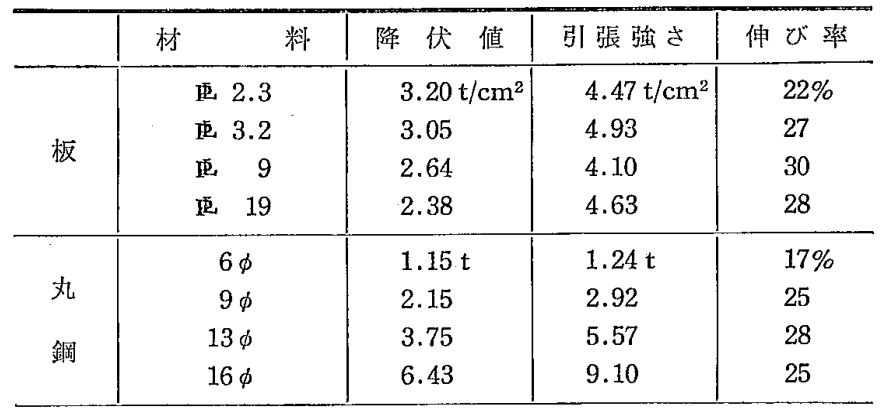

のである。特に丸鋼については W.S.Gにより $\sigma 一 \varepsilon$ 曲

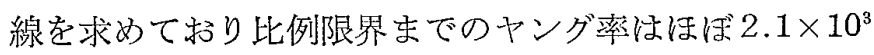
$\mathrm{t} / \mathrm{cm}^{2}$ の值吕出ている。

載荷トルクは載荷台にのせられた錘りと据り中心から のアーム距離から算出されるが，特にそのトルクの補正 として可動支点ボックスには 2 個の D.G. をセットして 据り角を求めている。これに伴う試験体各点の単位据り 角の測定は，A 6, A 12 試験体で $30 \mathrm{~cm}, A 18, \mathrm{~B}$ 試験 体でそれぞれ $60 \mathrm{~cm}, 40 \mathrm{~cm}$ の間隔をむって D.G. 2 個 を 1 組としてセットしている。丸鋼の反り拘束状態を 推し測るものとして軸歪と曲げ歪を測定するために，圧 縮を受ける 丸鋼と引張を受ける丸鋼の 2 本に対して, W.S.G. を A type で 8 点, B type で 4 点貼付してい る。特に A type で注基淮試験体としている A 12-9-13 についてのみ，測定箇所を 16 点としている。各ゲージ のセット位置は 図一3 の通りで，A type については基 淮試験体について示してある。

\section{実験結果}

A type の㨭りに対する性状は 2 節の理論解析ですで に述べたが，据り角 $\theta$ の材軸方向に対する变化は各卜ル クについてほとんぞ直線的で，丸鋼の影響は弦材自身の 㨭り角 $\beta$ に及ぼしここでいう梁の据り角では単位長さあ たりどの位置に祘いてもほぼ一致している。そしてこの 傾向は崩壊直前まで維持している。据り剛性は各節点で の相対据り角の平均より求めたもので，いずれも各下ル クをその時の単位㨝り角で除することにより得ている。 初期の状態では測定誤差の影響が大きく含まれ極端なば らつきがみられるものもある。各トルク時の実際の㨭り 剛性は，艺の時点での外力トルクと据り角それぞれの増 加分から求められるもので, 前法から得られる剛性曲線 よりむ，剛性低下の勾配はかなり大きくなる。崩壊のほ
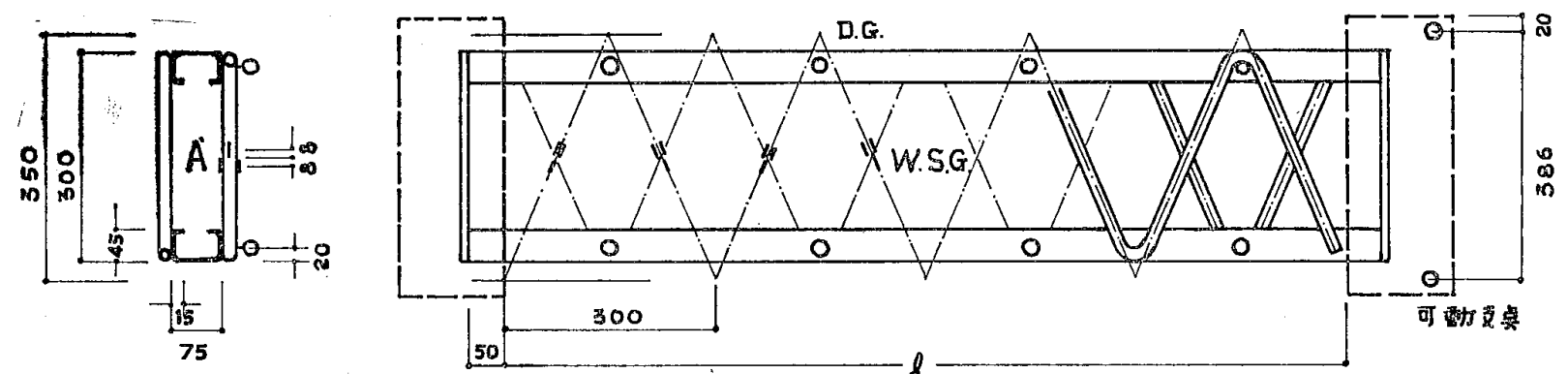

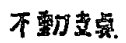
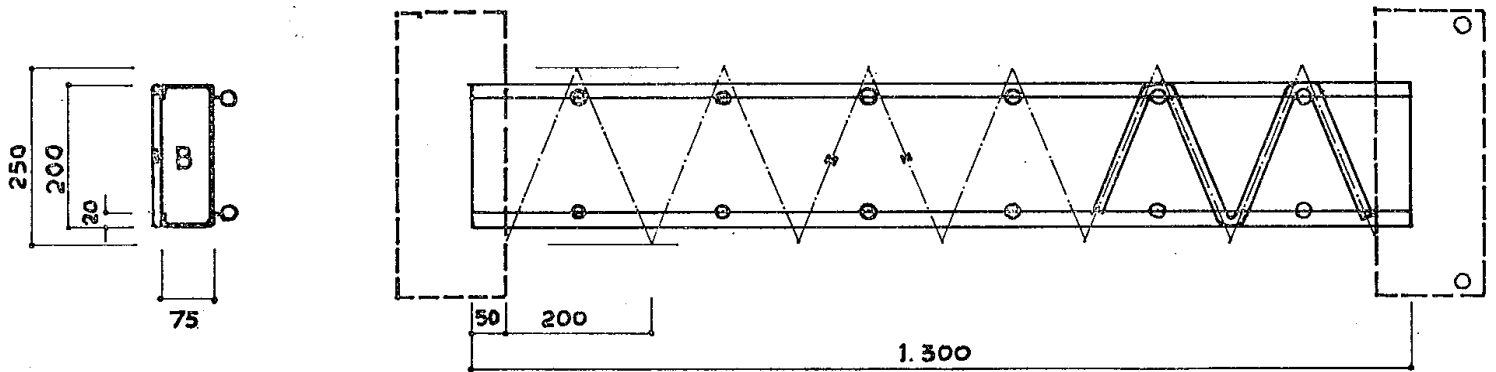

图一3 各試験体形状, 寸法, および測定箇所 
とんどは圧縮丸鋼の座屈によっている。そのため丸鋼の 応力状態は軸力については圧縮, 引張共にその絶対量は 等しく，均等に反りの拘束がなされているが，曲げ歪は 試験体の不完全性から座屈変形の生ずる位置がまちまち であって，測定箅所によって非常に大きく現わ叔るとこ ろもある。図一4 は基準試験体についての歪図で，他の 試験体についても, 同様の傾向を示している。図一5 は 各端部板厚に対する㨝り剛性曲線とその初期剛性の比較 グラフである。試験体材長はいずれも $1.3 \mathrm{~m}$ でかなりの 端部影響が入る。特に端部板のないものは断面の変形が 著じるしく剛性は極端に低くなる。しかし端部板による 反りの拘束がないため，丸鋼軸力は端部板のあるものよ り同トルクで約 3 割程大きな值を示す。端部板厚 $9 \mathrm{~mm}$ と $19 \mathrm{~mm}$ との比較では反りの拘束状態にほとんど差は ないが，端部板自身の剛性増加が伴うため板厚の大きい 程据りの耐力も上がる。端部板のないものは端部で局部 破壊が生じ計算值とは比較出来ない。図一6 は材長の剛

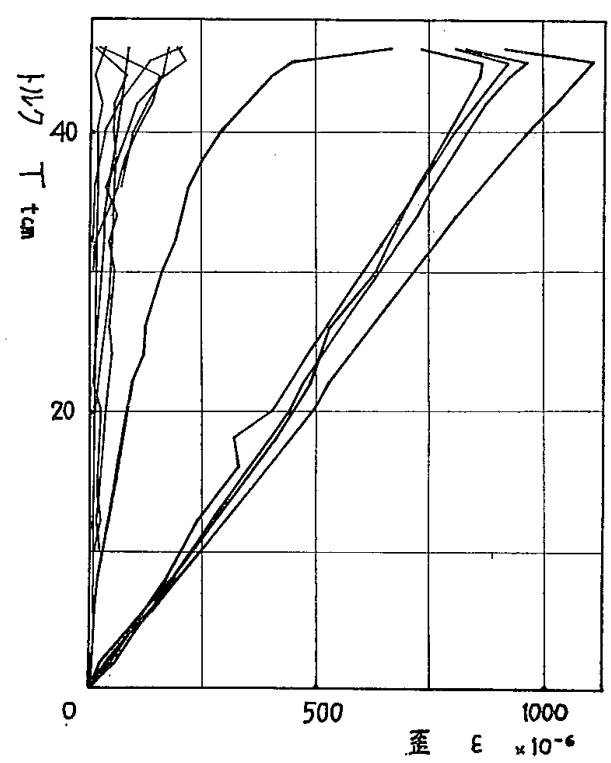

図一4 トルクー丸鋼軸，曲げ歪 (A 12-9-13)

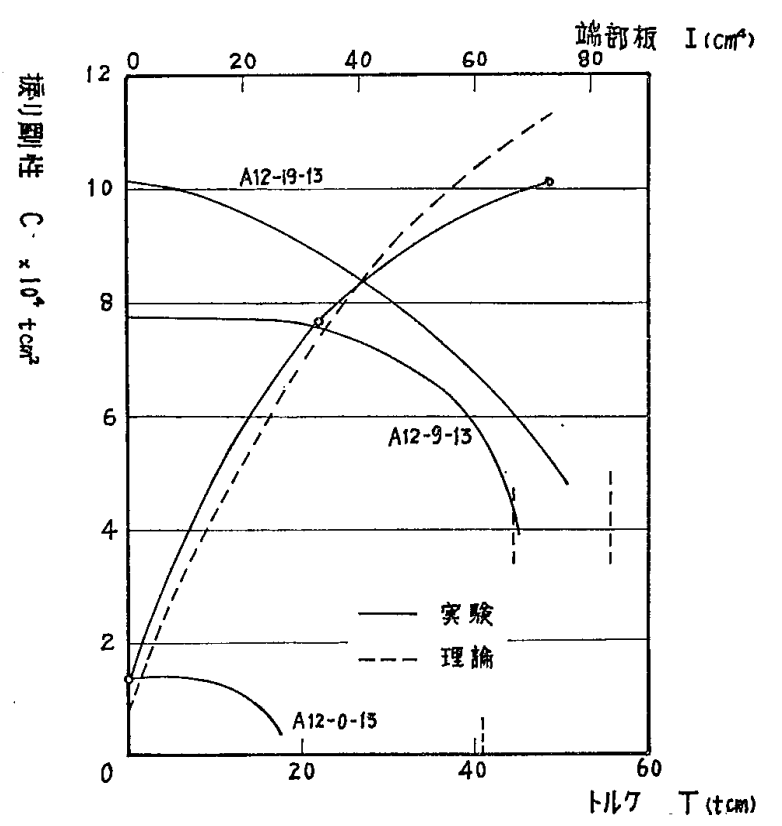

図一5 掘り剛性曲線-端部板厚变化
性に及ぼす影響を示す。図一7 は丸鋼径の変化によるも ので，㨝り剛性の増加が丸鋼の反り拘束すなわち軸力に よるためほぼその断面積に比例していることがわかる。

B type 試験体注組立梁というよりはむしろ丸鋼によ る補剛梁で，この解析には剛体棒に刘し剪断変形を考慮 に入れている。この場合の変位番号を図一8に示す。こ の種の補剛梁では A type での梁の据り角 $\theta$ と弦材の据 り角 $\beta$ が一致するので反りの拘束が直接梁の据り角に影 響を及ぼす。しかし据り剛性の算出にあたっては A type と同様相対据り角の平均值より求めている。図一9 は各 丸鋼径に対する据り剛性曲線とその初期剛性の比較グラ フである。 $9 \mathrm{~mm} \phi$ 丸鋼以下補剛丸鋼の岡性が小さい場合 は比較的計算值に合っているが，それ以上になると被補 剛材であるミゾ型鋼自身の断面変形の影響が入り，単純 に丸鋼面積に比例しなくなる。16 $\mathrm{mm} \phi$ 丸鋼以上ではほ とえど捖り剛性の増加は期待出来ない。

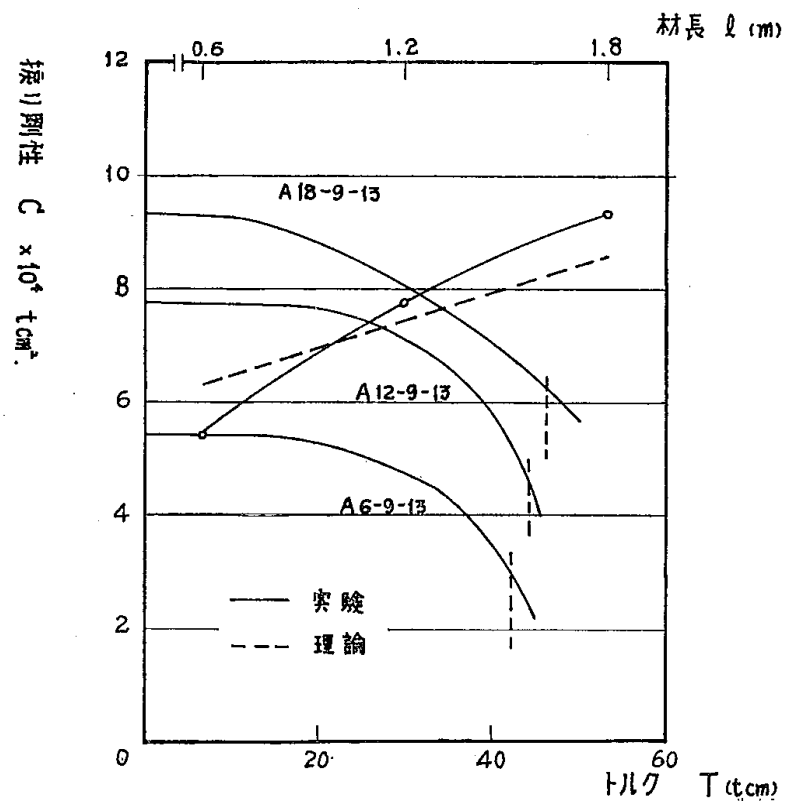

図一6 掘り剛性曲線-材長变化

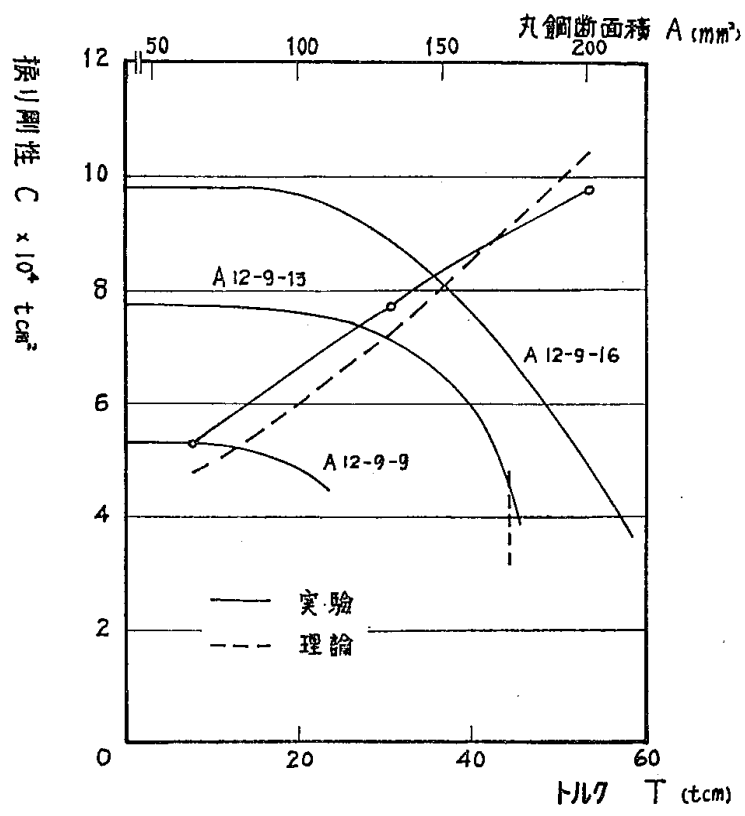

図一7㧖り剛性曲線一丸鋼径変化 


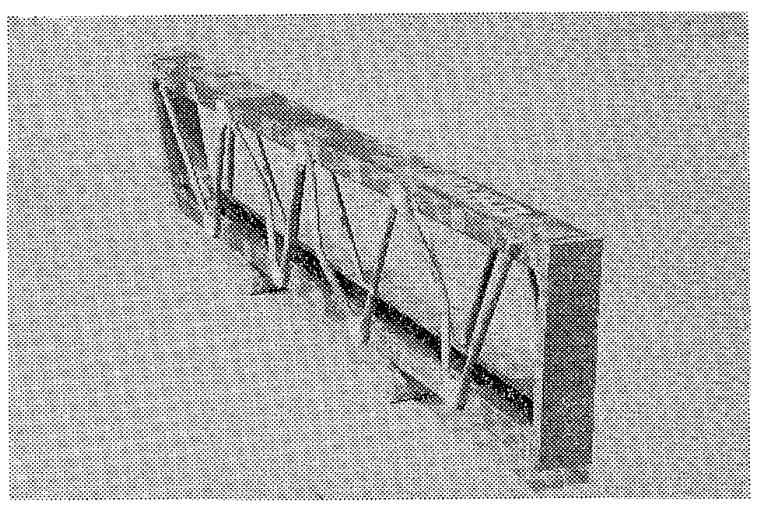

写真-4 A type 丸鋼座屎

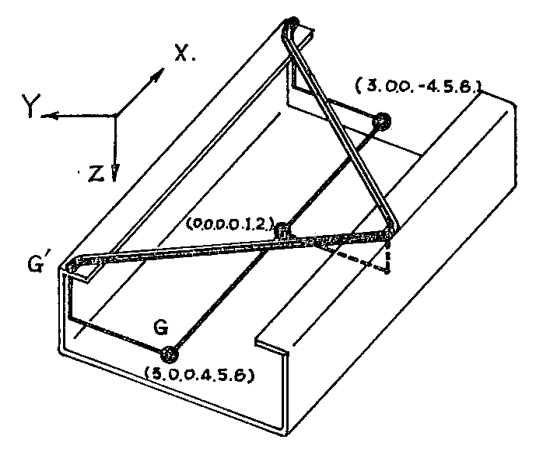

図-8 B type 変位番号

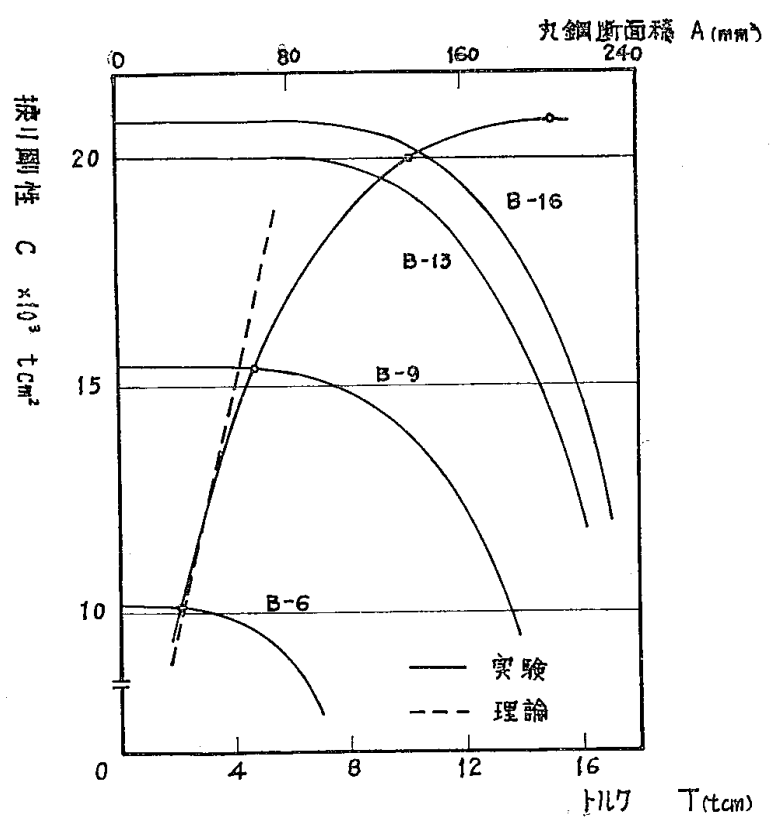

図一9椖り剛性曲線

\section{§4. 考 察}

組立梁の据り問題に限ぎらず種々の架榜に対する解析 において，A type の弦材に見られるよらな部材幅の考 慮を必要とする場合がよくある。この部材幅に刘して材 長が比較的大なる場合，ここで取り报った剛体棒の置換 は有效な手段となる。ただし剛体棒のとりかたが直接反 り変形に大きく影響を及ぼすことから，節点位置の選定 には十分注意を要するものである。また B type のよう な部材そのものの補剛による剛性の增加を解析する場合

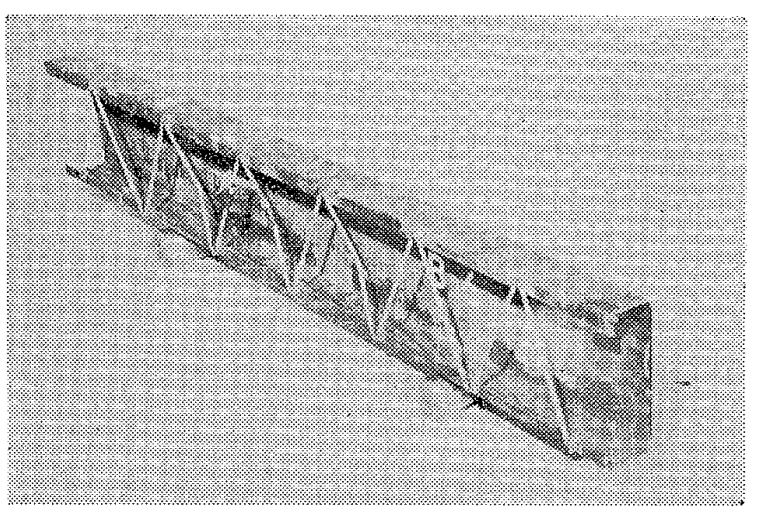

写真一5 B type 丸鋼座属

補岡材剛性が堌強寸ると，これによる被補剛材の局部的 な変形をきたし当初の仮定である部材断面形の不変にか なりの無理が生ずる。

さて以上の㨭り解析にあたり組立梁の㨝りに関して， ほぼ次のことが結論の゙けられる。

1. A type のような組立梁の㨝り剛性は，弦材自身 の剛性に比して丸鋼による反り拘束から生ずる剛性増 加が压倒的であり，ほぼ丸鋼面積に比例するものであ る。

2. 材端板厚による端部補強の影響は当然板のないも のに比して相当増加するが，これは材長と密接な関連 があって，むしろここで取り报ったよらな短い梁の端 部補強のないものは特殊といってもさしつかえない。 端部の局部破鉬防止のうえにも端部板などによる補剛 は当然必要ではあるが，建築などで取り扱われる梁の 材長においては，ほとんど端部による影響は無視され 得る。A type の組立梁に扔て 1 エニットの場合， 端部固定としての据り剛性は端部自由に比して実に 30 倍近い差が見られるが，6ニニットの長さに增し た時 1.5 倍程度にまで近づくことからも推し测ること が出来る。

3. 㧖り耐力の問題では, すでに述べた通り補剛丸鋼 の軸力にほとんど左右され，これは弦材を単に強くす ることが耐力の向上にはならないことを意味してい る。弦材の愊が大きくなれば丸鋼の反り拘束が著じる しく単位㨭り角当りの丸鋼軸力が増加して, 据り剛性 そのものは増すが逆に耐力は低下することになる。

\section{参考文 献}

1) F. Laszlo and H. Nolle : "On the Torsional Stiffness of Box Section Girders" The Struct. Engr. 6105 163-173

2）島田静雄：“鋼薄肉矩型断面の据れ実験 おょび 理論的検 討”土木学会論文集 Vol. 114, 6502 17-33

3) S.S. Tezcan : "Computer Analysis of Plane and Space Structures" Proc. A.S.C.E S.T.D, Vol. 92, No. S.T 2, 6604, 143-173

4) R.W. Woodhead and A.S. Hall : "Frame Aanalysis" John Wiley \& Sons. Inc. 1958 


\title{
TORSION OF BUILT-UP GIRDER
}

by Dr. TOSHIRO SUZUKI Assistant Prof. of Nagoya Institute of Tech., MAMORU KIMURA Structural Engineer of Takenaka Komuten Co., Ltd., Members of A.I.J.

The pourpose of this paper is to analyze the torsional problem of built-up girder with the stiffness matrix method.

The stiffness matrix method is finally equal to the displacement method which is satisfied the equilibrium conditions at the points of contact. But on the semi-closed section, we must consider the width of member.

Then, we assumed as followes

1) The cross section area of member is undeformed and remains plane

2) The torsional rigidity of each member is only St. Venant's torsion.

From these two assumptions, making the transformation matrixes of the stress, $T_{f}$, and the deformation, $T_{u}$, the main stiffness matrix reads

$$
K=T_{f} T^{T} k T T_{u}
$$

where $T$ is the co-ordinate transformation matrix and $k$ is the individual member stiffness matrix. Farthe. in order to check the appropriateness of this theory, we experiment. Generaly, in this kind of the torsional exp $i-$ ments of built-up girder, the influence of warping restraint is significant. Then on our experiments, we design $t$; experimental system without restraint.

The summary of this paper is as follows.

1) On analyzing the space frame, if we must consider the width of member, it is useful that we analyze with substituting the stiffened rod for the width of member.

2) The member of short length is influenced by the condition of ends, and the torsional rigidity decrease owing to the deformation of cross section on the end.

3) Increase of the torsional rigidity is due to the restrain of warping deformation for the most part.

U.D.C. $620.173: 624.074$

\section{TEST ON WELDED STEEL TRUSSES ADAPTED T-STRUCTURAL SHAPE FOR CHORD MEMBERS AND STEEL TUBE FOR WEB MEMBERS}

\author{
(Eccentric Panel Points : Part 3•1)
}

by Dr. KOICHIRO YAMADA, Prof. of Fukui Univ., Member of A.I.J.

This paper is the continuity of the previous paper written by the author in Transactions of Architectural Institute of Japan, No. 126, in August 1966. In this paper, in order to prevent the lateral buckling in testing a specimen constructed of the same two welded steel trusses, adapted the $T$-structural shape for their chord members, the steel tube for their web members and the eccentric panel points to make the construction of their panel points as simple as possible, was tested to find their strength and rigidity in the elastic and plastic behaviors. And the results of this test are discussed in comparison with the results of the elastic and plastic theoretical analysis, in which the second stresses for the welded steel trusses are considered and the plastic hinge theorem based on several assumptions is applied.

The results are as follows.

1) The yield load of the specimen in this test was nearly 23 tons and for larger loads than the yield one its rigidity was observed to decrease remarkably. And the above mentioned elastic and plastic behaviors of the specimen were found to nearly satisfy the results of this theoretical analysis.

Especially the elastic and plastic behaviors of the specimen in the process of its load becoming the yield one were sufficiently explained by this theoretical anailsis. And the yield load of the specimen, owing to the plastic hinges formed in its web members and the yielding of its lower chord member due to the tensil axial force and bending moment, was found to correspond to the limited load in which the specimen should lost most of the organization of the welded steel trusses and its upper chord member should begin to act as a beam.

However, the rigidity of the specimen for larger loads than the yield one was found to become larger than that of this theoretical analysis.

2) The dameges to the panel points of the specimen could not be observed until its breaking load due to the buckling of its compressive web member.

U.D.C. 725.51.011.1

\section{NUMBER OF PATIENTS RECEIVING PHYSIOLOGICAL TEST}

- Studies in the Functions and Design of Hospitals-

by Dr. MAKOTO ITO, Associate Prof. of Chiba Univ., Member of A.I.J.

The number of physiological test in hospital is increasing. The information as to the use of physiological test 